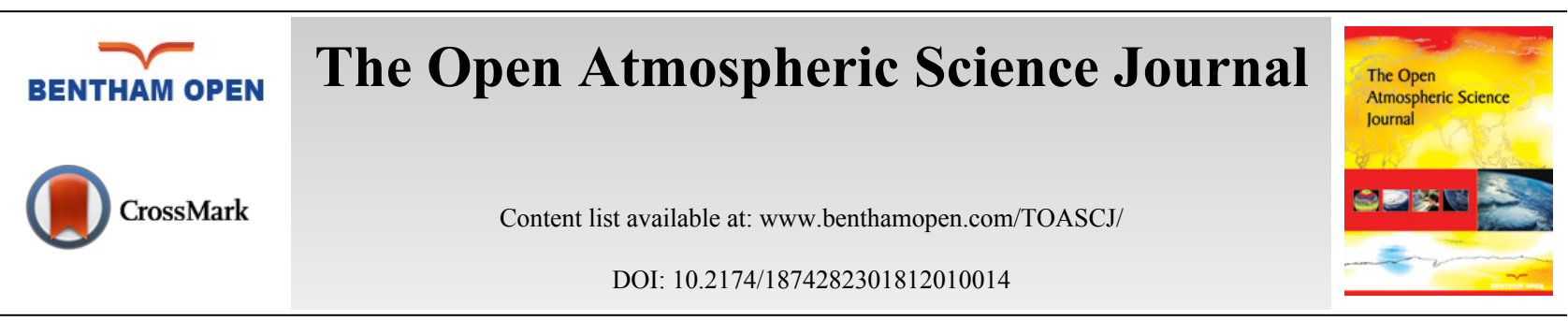

RESEARCH ARTICLE

\title{
Contamination by Coal Dust in the Neighborhood of the Tarragona Harbor (Catalonia, Spain): A Preliminary Study
}

\author{
Joaquim Rovira ${ }^{1,2}$, Marta Schuhmacher ${ }^{1,2}$, Martí Nadal $^{2}$ and José L. Domingo ${ }^{1, *}$

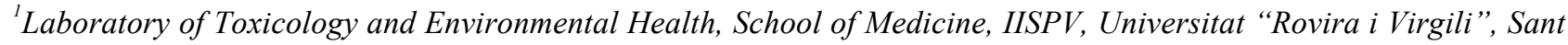 \\ Llorenç 21, 43201 Reus, Catalonia, Spain; \\ ${ }^{2}$ Departament d'Enginyeria Química, Universitat Rovira i Virgili, Av. Països Catalans 26, 43007 Tarragona, Catalonia, \\ Spain
}

Received: December 25, 2017

Revised: March 13, 2018

Accepted: April 04, 2018

\begin{abstract}
:
Background:

In February 2017, some buildings of La Pineda (Catalonia, NE Spain) a rather small town, located near to the Tarragona harbor, were affected by a contamination episode that dirtied external walls, windows, doors and floors of these buildings with a black dust. This study was aimed at assessing the origin of the black dust appeared in the buildings.
\end{abstract}

\section{Methods:}

Black dust samples were collected in the railings of balconies, windows, and exterior doors of two buildings in La Pineda, as well as in the ground of the breakwater of the Tarragona harbor, at few meters from the open air coal storage area. Elemental analysis of the black dust (C, N, H and S) was performed. A daily sample of $\mathrm{PM}_{10}$ was also collected and analyzed for five consecutive days.

\section{Results:}

The total carbon content of the collected dust was $25.8 \%, 29.4 \%$ and $33.9 \%$ in the two buildings of La Pineda and the breakwater, respectively. In turn, the contribution of carbon from carbonates was $0.0 \%, 1.3 \%$ and $5.1 \%$, in the samples of the two buildings and the breakwater, respectively. $\mathrm{PM}_{10}$ showed levels between 18 and $39 \mu \mathrm{g} / \mathrm{m}^{3}$, with mean and median levels of $29 \mu \mathrm{g} / \mathrm{m}^{3}$.

\section{Conclusion:}

The elemental analysis indicated that the two black dust samples collected in the two buildings of La Pineda were similar to the sample collected at the breakwater of the port of Tarragona, showing a common origin: The bulk coal storage area of Tarragona harbor. Because information on the human health risks derived from the important activities conducted in the port of Tarragona is currently non-existent, an exhaustive assessment of all pollutants involved in the activities of the port is strongly recommended.

Keywords: Tarragona harbor, Neighborhood, Environmental impact, Black dust samples, Winds, La Pineda.

\section{INTRODUCTION}

Tarragona is an important industrial city located in the South of Catalonia, Spain. Since approximately 50 years ago, one of the largest chemical and petrochemical industrial complexes in Southern Europe is located in Tarragona County. The presence of a highway and various roads with a heavy traffic influences enormously the environment of the area, in which a considerable number of industries are operating. These include currently a big oil refinery (Repsol Petróleo, S.A.), as well as a number of chemical and petrochemical industries. Moreover, a Municipal Solid Waste Incinerator

\footnotetext{
"Address correspondence to this author at the Departament d'Enginyeria Química, Universitat Rovira i Virgili, Av. Països Catalans 26, 43007 Tarragona, Catalonia, Spain; Tel: 34977 759380; E-mail: joseluis.domingo@urv.cat
} 
(MSWI), and the only Hazardous Waste Incinerator (HWI) of Spain are also located in the same area. Because of the emissions of a number of pollutants potentially released by these industries and activities, public concern over possible adverse health effects for the population living in Tarragona city and surroundings zones is continuous and permanent $[1,2]$.

For their usual daily operations, most of the industrial activities above indicated require the support of an important harbor. The port of Tarragona is located on the NE Spanish coast $\left(41.09^{\circ} \mathrm{N} ; 1.22^{\circ} \mathrm{E}\right)$. It is an industrial bulk carrier port. Although the economic structure of the hinterland of the harbor is strongly based on the petrochemical industries, the traffic of other kinds of goods is also considerable. In addition, since 1975, Repsol Petróleo, S.A. is operating its own oil terminal, which includes a floating dock (monobuoy). The long dock and the monobuoy are highly active sites. In recent years, and basically during the summer, the port of Tarragona has incorporated the periodical arrival of a number of cruises. Doubtless, the important activities carried out in the Tarragona harbor should mean an environmental impact, and probably, also certain health risks for the population living in the neighborhood. However, information on the environmental and health risks, currently available in the scientific literature, is certainly very scarce. It is limited on one side, to environmental risk analysis of aquatic systems as a result of exposure to one or more stressors, based on the oil handling in that port $[3,4]$, while on the other hand, a few studies have estimated the impact of the harbor activities on $\mathrm{PM}_{10}$ concentrations $[5,6,7]$.

Recently, specifically between February 12 and 13, 2017, some buildings of La Pineda (Catalonia, NE Spain) $\left(41.07^{\circ} \mathrm{N} ; 1.18^{\circ} \mathrm{E}\right)$, a rather small village (around 3,000 inhabitants) located at $10 \mathrm{~km}$ from Tarragona, but closer to the Tarragona harbor, were affected by a contamination episode that dirtied external walls, windows, doors and floors of these buildings with a black dust. According to the information reported by the people living in the affected buildings, the main suspect of the dust origin was the open air bulk coal mountains located in the storage area of the Tarragona harbor. These affected buildings are located approximately at $3.5 \mathrm{~km}$ West-Southwest (WSW) of the bulk coal storage area of Tarragona harbor (Fig. 1). The residents in the affected buildings of La Pineda reported to suffer these episodes at least once per year, for a long time. These episodes, in addition to the obvious annoying consequences, also could produce health problems and negative effects on the local economy, as the tourism is the main economic activity in La Pineda.

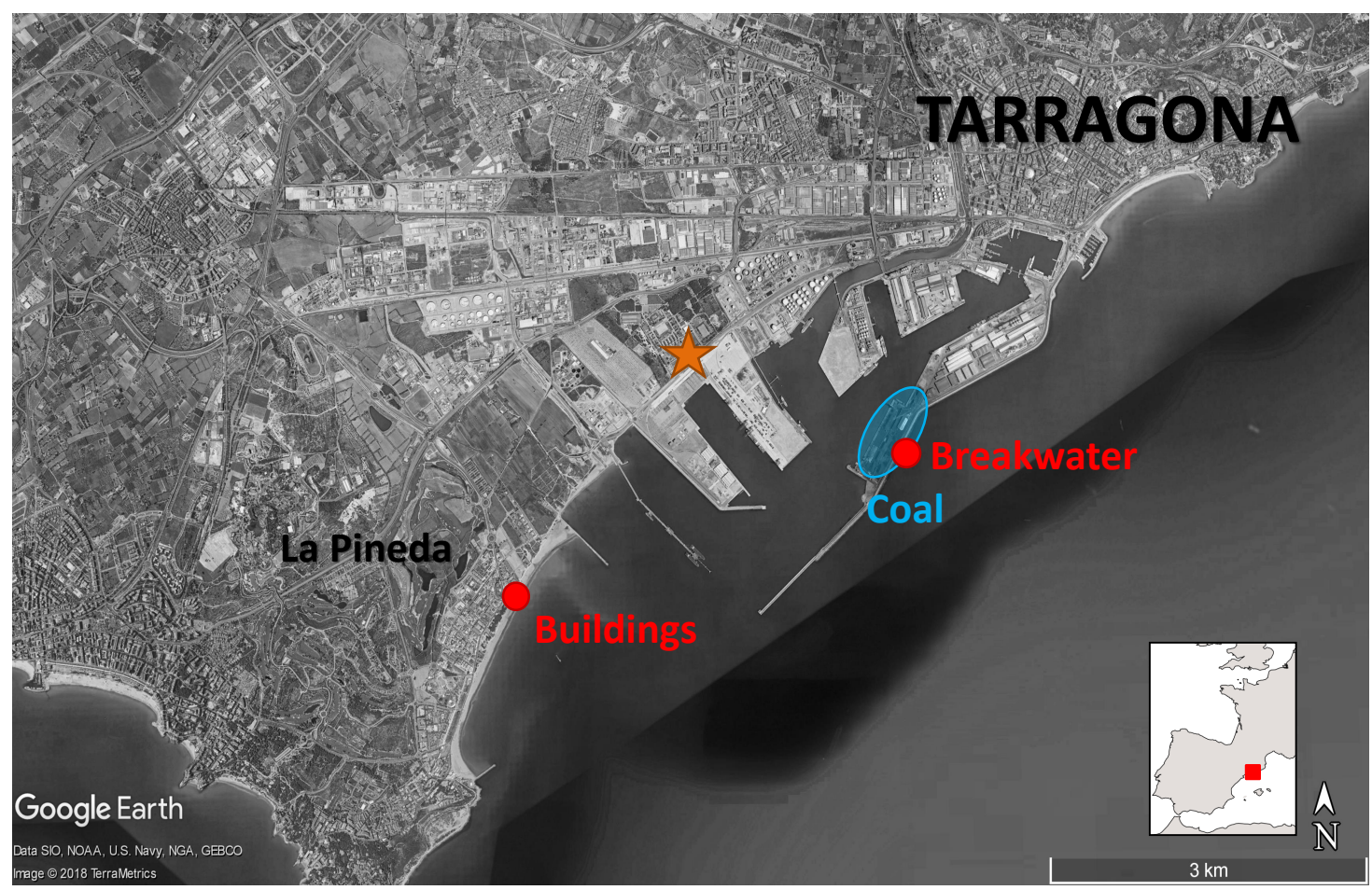

Fig. (1). Map of La Pineda and Tarragona harbor. The coal storage area and the sampling points (two buildings in La Pineda and breakwater) are marked. The meteorological station location is marked with a star.

Because of the interest and concern raised by that episode, the present study was aimed at scientifically assessing 
the origin of the black dust appeared in the buildings of La Pineda in February 12-13, 2017. To find out the origin was an important goal for the inhabitants of La Pineda, as well as for other people living in the area under influence of the Tarragona harbor, in order to be able of preventing further episodes, which in turn could mean potential health risks, such as cardiorespiratory diseases, or even cancer. As above commented, information on the human health risks derived from the important activities conducted in the port of Tarragona is currently non-existent. Meteorological data, back trajectories, and elementary analysis were integrated to achieve our objective.

\section{MATERIALS AND METHODS}

A few days after the contamination episode (February 20), black dust samples were obtained in the railings of balconies, windows, and exterior doors of two buildings in La Pineda (two samples in two different buildings), as well as in the ground of the breakwater of the Tarragona harbor (one sample), a few meters from the open air coal storage area (Fig. 1). Samples were collected using a laboratory spatula avoiding collecting wet samples and foreign elements such as sand, top-soils, etc. Each sample was composed of various subsamples.

For the elemental analysis of the black dust (C, N, H and $\mathrm{S}$ ), a part of the sample was burned by combustion with an oxygen atmosphere at $1,000^{\circ} \mathrm{C}$. The resulting gases $\left(\mathrm{SO}_{2}, \mathrm{CO}_{2}\right.$ and $\left.\mathrm{NO}_{\mathrm{x}}\right)$, dragged by helium current, were analyzed by gas chromatography (Thermo EA 1108 CHNS-O Carlo Erba Instruments). For the analysis of carbon from carbonates, each sample was previously exposed to an atmosphere of Hydrochloric acid $(\mathrm{HCl})$, being subsequently analyzed using the same methodology.

Additionally, a daily sample of $\mathrm{PM}_{10}$ was collected for five consecutive days (from Monday to Friday, in two consecutive weeks, starting on May 29, and June 5, 2017), according to the meteorological forecast. The sample was collected with a high volume MCV sampler (Collbató, Barcelona, Spain). The volume collected was approximately $718 \mathrm{~m}^{3}$ for each sample. It was collected in Quartz Fiber Filters (QFFs) of $150 \mathrm{~mm}$ diameter. QFFs were previously heated at $200^{\circ} \mathrm{C}$ for 4 hours to eliminate potential Volatile Organic Compounds (VOCs). Previous and after the sampling, QFFs were acclimated for 24 hours, at a relative humidity of $40 \%$ and at a temperature of $25^{\circ} \mathrm{C}$, being weighed in several consecutive days, at same conditions, in order to determine gravimetrically the $\mathrm{PM}_{10}$ levels.

Meteorological data were obtained from an automatic station of the Catalonia Weather Service, which is located at the Tarragona Educational Complex (at $2 \mathrm{~km}$ from the coal storage area) [8]. In addition, the HYSPLIT model developed by the National Oceanic and Atmospheric Administration of the United States, adapted to Spain for the calculation of retro-trajectories, was applied [9, 10]. The model, widely used by the scientific community, provides information regarding where the air comes from.

\section{RESULTS}

The wind direction (blowing from), and its average and maximum speed recorded every half hour from February 10 to 16, 2017, is depicted in Fig. (2). As it can be seen, from 12 noon on February 11 until 8:00 PM on February 13, the wind blew between $57^{\circ}$ (North-East) and $85^{\circ}$ (East), with an average of $74^{\circ}$. The wind direction blew from Tarragona harbor to La Pineda. Moreover, the wind speed was increasing between the 00:00 of February 11 until reaching a maximum wind speed peak of $58 \mathrm{~km} / \mathrm{h}$ at 12 noon on February 12. A second maximum peak was reached at 08:00 AM of February 13 (maximum wind speed of $61 \mathrm{~km} / \mathrm{h}$ ), after which the speed decreased to average speed values around 5 $\mathrm{km} / \mathrm{h}$, with a maximum speed of $20 \mathrm{~km} / \mathrm{h}$. Therefore, the combination of sustained winds blowing from between NorthEast and East with high wind speed, clearly suggests that the origin of the black dust was the Tarragona harbor. The annual average wind speed in the area is $8.3 \mathrm{~km} / \mathrm{h}$.

The HYSPLIT model was applied to calculate eighteen $12 \mathrm{hr}$-back trajectories from February 11 at 12:00 AM to February 13 at 12:00 PM, with a time resolution of 2 hours between trajectories (Fig. 3). Air masses came from the Mediterranean Sea, passing some of them above the Tarragona harbor facilities, where the bulk coal is stored. Furthermore, air masses were at almost ground/sea level when passed through the harbor facilities, before arriving at La Pineda's buildings. 

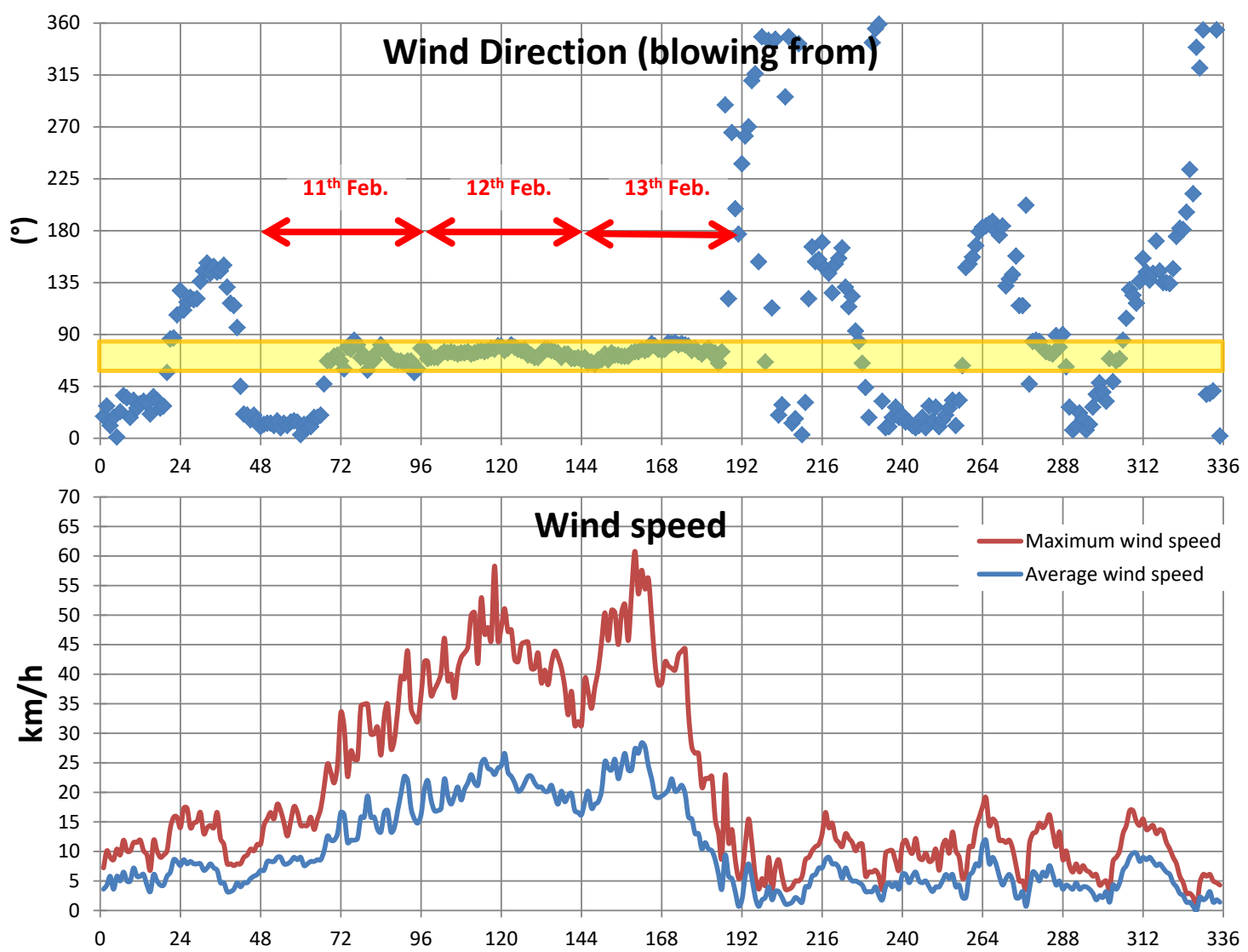

Fig. (2). Wind direction (blowing from) and speed in $(\mathrm{km} / \mathrm{h})$ obtained from the Catalonia weather service station located in the Tarragona Educational Complex. The X axis in semi-hours from 0 (0:00, 02/10/2017) to $336(11: 30 \mathrm{PM}, 02 / 16 / 2017)$. The directions of the wind that affects La Pineda from Tarragona harbor carbon storage are highlighted in the yellow box.

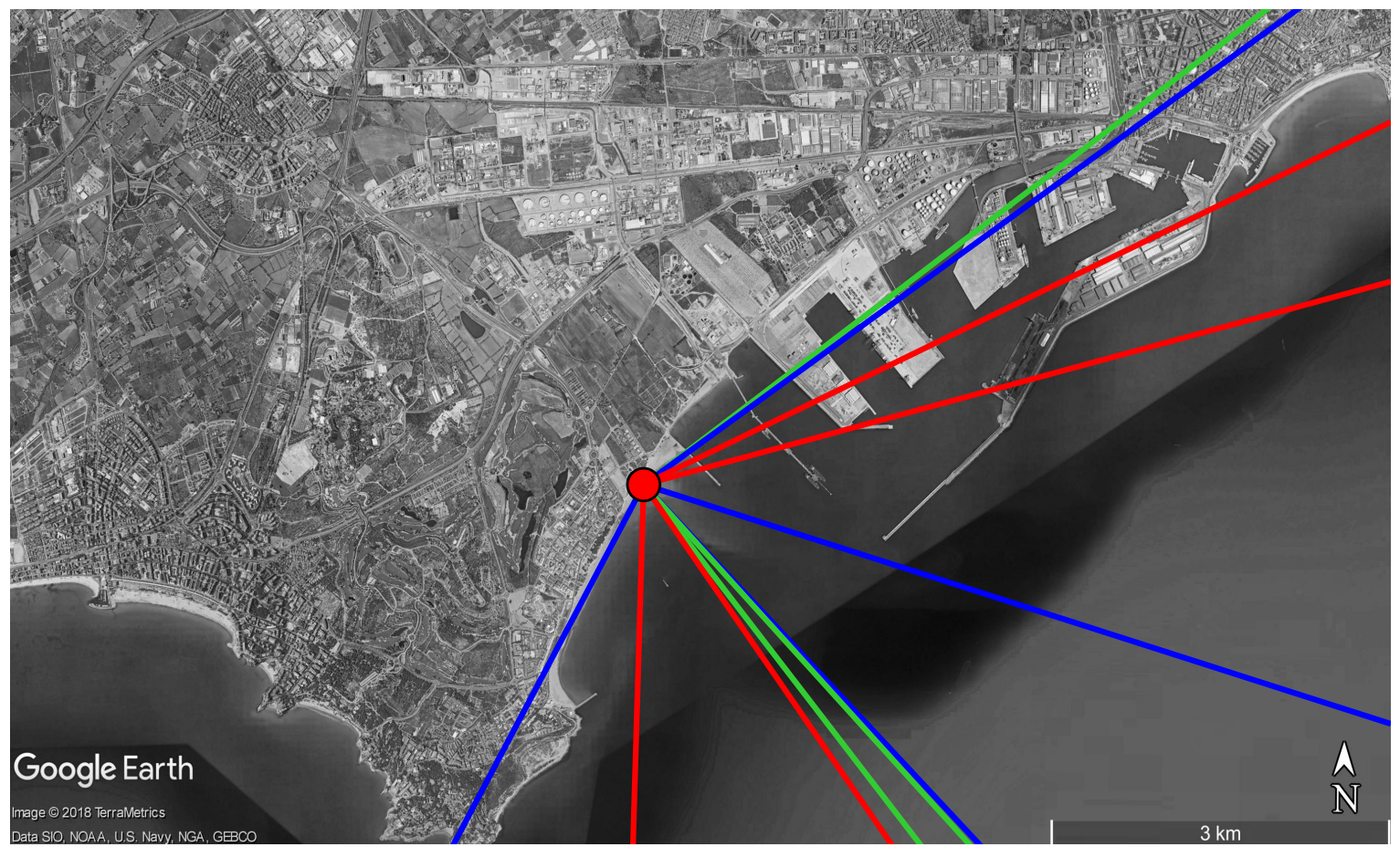

Fig. (3). Back trajectories during the contamination episode. A total of 18 trajectories (12 hours of duration) were calculated every 2 hours, from February 11, 2017 at 12:00. 
The results of the elemental analysis of the black dust samples collected in the breakwater of Tarragona harbor, as well as in the two buildings located in La Pineda are summarized in Table 1. The total carbon content of the collected dust was $25.8 \%, 29.4 \%$ and $33.9 \%$ in the two buildings of La Pineda and the breakwater, respectively. In turn, the contribution of carbon from carbonates was $0.0 \%, 1.3 \%$ and $5.1 \%$, in the samples of the two buildings and the breakwater, respectively. The sample of the breakwater was collected from the ground, while in the buildings of the Pineda sampling collection was done in windows, doors, and railings of balconies. It would explain the different content of carbonates, which are a very common constituent of rocks and minerals of the earth's crust, and even other materials such as cement. Consequently, the contents of carbon not originated from carbonates (not from minerals) were $25.8 \%$ and $28.1 \%$ in the two buildings, and $28.8 \%$ in the breakwater, results that are all very similar. These carbon levels were in accordance with the typical content of carbon in non-dried coal. The elemental analysis indicates that the two black dust samples collected in the two buildings of La Pineda are similar to the sample collected at the breakwater of the Port of Tarragona, showing a common origin.

Table 1. Elemental composition of black dust found in the two buildings of La Pineda and in the breakwater of Tarragona harbor, near a coal storage area.

\begin{tabular}{|l|c|c|c|c|c|}
\hline & $\mathbf{\% ~ N}$ & $\mathbf{\% ~ H}$ & $\mathbf{\%} \mathbf{S}$ & $\begin{array}{c}\mathbf{\% C} \\
\text { Total }\end{array}$ & $\begin{array}{c}\text { \%C } \\
\text { carbonates }\end{array}$ \\
\hline La Pineda building 1 & 0.78 & 1.87 & 1.14 & 25.8 & 0.00 \\
\hline La Pineda building 2 & 0.77 & 2.10 & 1.38 & 29.4 & 1.30 \\
\hline Breakwater of Tarragona harbor & 0.80 & 2.36 & 1.50 & 33.9 & 5.11 \\
\hline
\end{tabular}
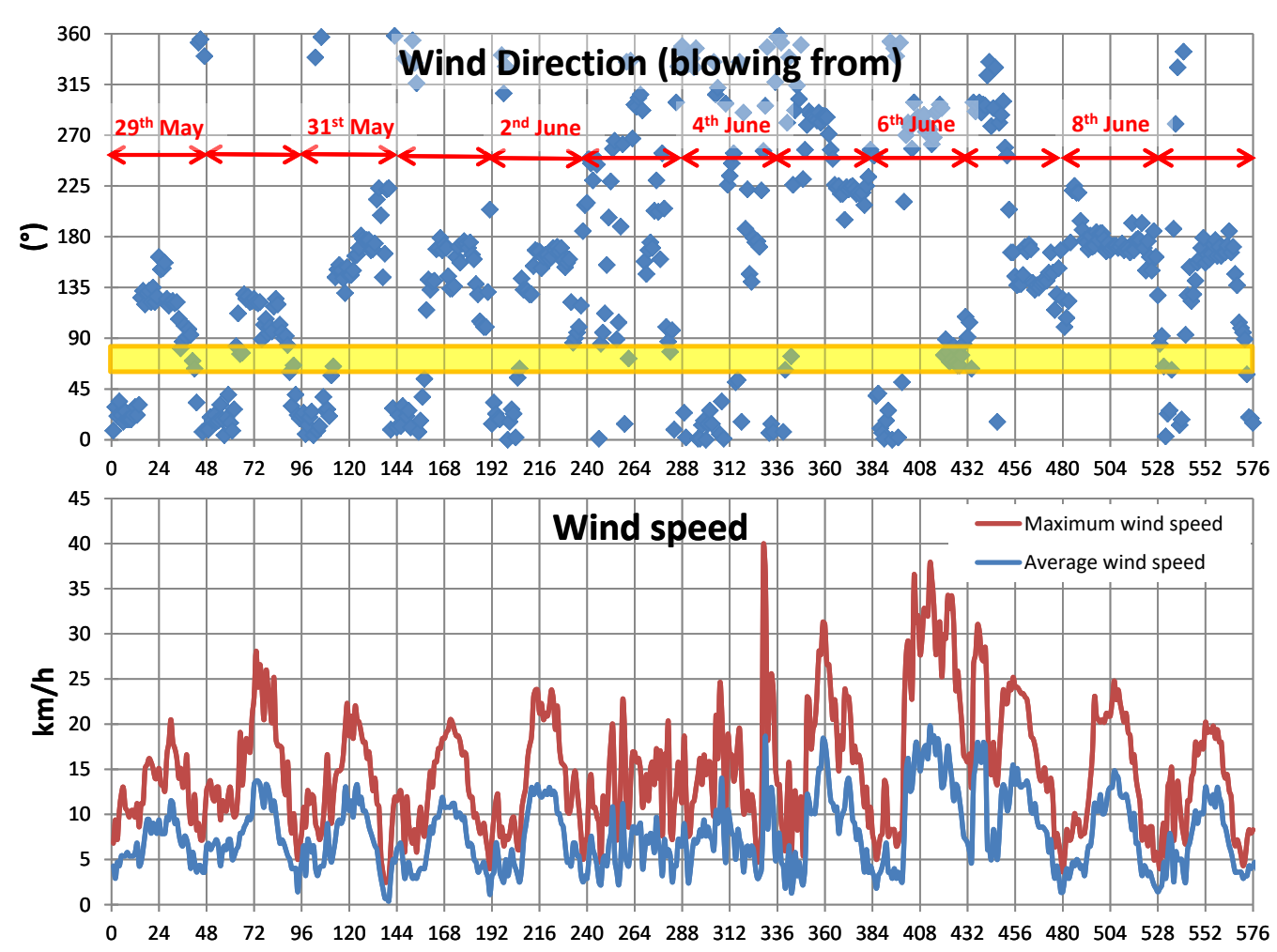

Fig. (4). Wind direction (blowing from) and speed in $\mathrm{km} / \mathrm{h}$ obtained from the Catalonia weather service station located in the Tarragona Educational Complex during sampling campaign. The X axis in semi-hours from 0 (0:00, 05/29/2017) to 576 (11:30 PM, 06/09/2017). The wind directions that affect La Pineda from the Tarragona harbor carbon store are highlighted in the yellow box.

$\mathrm{PM}_{10}$ collected between May 29 and June 9, 2017, showed levels between 18 and $39 \mu \mathrm{g} / \mathrm{m}^{3}$, with mean and median levels of $29 \mu \mathrm{g} / \mathrm{m}^{3}$. However, during the sampling period, wind conditions (direction and speed) were not reproducing the conditions of February winds (from E and NE with speed above $35 \mathrm{~km} / \mathrm{h}$ ), when the contamination episode occurred (Fig. 4). For that reason, no further analyses were done regarding $\mathrm{PM}_{10}$ samples. According to the scientific literature, previous data on $\mathrm{PM}_{10}$ in the Tarragona harbor are very limited. In 2007, Alastuey and co-workers [7] reported the 
results of a study aimed at estimating the impact of harbor activities on $\mathrm{PM}_{10}$ levels based on a complete chemical characterization of $90 \mathrm{PM}_{10}$ samples, which were periodically collected between September 2004 and September 2005 in the harbor of Tarragona. The multi-linear regression analysis demonstrated a high anthropogenic contribution (62\%) for $\mathrm{PM}_{10}$ at the harbor, mainly related to traffic $\left(34 \%\right.$ of $\left.\mathrm{PM}_{10}\right)$. Moreover, given the high volume of solids in bulk handled in the harbor of Tarragona, Moreno et al. [6] selected 12 handling operations of a number of materials (clinker, phosphate, pyrite ash, Mn mineral, fine Si-Mn, coke (coal), bituminous coal, tapioca, soybean, alfalfa, corn, andalusite) for the characterization of suspended and deposited PM. In spite of the coarse grain size distribution of these bulk cargo materials -with a very low percentage in the fraction $<10 \mu \mathrm{m}$ - the manipulation of these materials during harbor operations might result in high emissions of $\mathrm{PM}_{10}$, with relatively high levels of potential toxic elements. In turn, Artiñano et al. [5] assessed the impact of specific handling operations and bulk materials in the port of Tarragona. Materials such as silica-manganese powder, tapioca, coal, clinker and lucerne were dealt with during the studies. The highest impact on ambient particle concentrations corresponded to the handling of clinker. For clinker, as well as for silica-manganese powder, high levels were recorded in the fine grain size $(<2.5 \mu \mathrm{m})$. In contrast, the lowest impact on PM concentrations was observed during handling of tapioca and lucerne, mainly in the coarse grain size $(2.5-10 \mu \mathrm{m})$.

\section{CONCLUSION}

When assessing the potential health risks in the vicinity of a harbor like the current one, it should be taken into account that coal can contain heavy metals and metalloids ( $\mathrm{As}, \mathrm{Cd}, \mathrm{Cr}, \mathrm{Hg}, \mathrm{Pb}, \mathrm{Mo}, \mathrm{Zn}$ ), as well as other substances that could be harmful to human health [11]. The people living in La Pineda not only could be exposed to these elements through dust inhalation, but also through dust ingestion and dermal contact when the coal dust is re-suspended or infiltrated to indoor environments.

From February 11 to 13, 2017, the wind speed (maximum above $55 \mathrm{~km} / \mathrm{h}$ ) and the direction blowing from East and North-East showed the ideal conditions for the dispersion of material from the bulk coal storage area of Tarragona harbor towards La Pineda. The retro-trajectory analysis during those days confirmed that the origin of the air mass came from the sea and passed over the facilities of Tarragona harbor to La Pineda's buildings. Elemental analysis of the black dust obtained confirmed the high carbon contents (25.8-29.4\%), with a minimal contribution of carbon from carbonates (0.0-1.3\%). In addition, the content of carbon -not from carbonates- was similar in the samples collected in the buildings of La Pineda (25.8-28.1\%) and in the sample collected in the breakwater (28.8\%). These results clearly indicate that the black dust in the buildings of La Pineda, which was noted in February 12-13, 2017, was due to the dispersion produced by the wind from the coal mountains in the bulk storage area of the Tarragona harbor.

Although these episodes of strong winds blowing from East (E) and Northeast (NE), locally called "Llevantades", are occasional, they are not rare in the Catalan Mediterranean sea area. The location of the Tarragona harbor, near populated areas such as La Pineda or Tarragona city, can mean, in addition to the obvious annoying dust outbreaks episodes, potential health risks for the population of the zone. Consequently, we suggest the following actions as a priority: 1) to conduct the necessary actions to reduce future dispersion events that may affect populated nuclei, 2) to perform environmental sampling campaigns in order to establish $\mathrm{PM}_{10}$ levels and components content during any potential coal contamination episode, and 3) to carefully assess the potential effects of coal on the health of the population living in the neighborhood of the Tarragona harbor. For a complete knowledge of the environmental and health risks, an exhaustive assessment of all pollutants involved in the activities of the port is strongly recommended.

\section{CONSENT FOR PUBLICATION}

Not applicable.

\section{CONFLICT OF INTEREST}

The authors declare no conflict of interest, financial or otherwise.

\section{ACKNOWLEDGEMENTS}

J. Rovira receives funds from Health Department of Catalonia Government, trough "Pla Estratègic de Recerca $\mathrm{i}$ Innovació en Salut" (PERIS 2016-2020) fellowship (SLT002/16/00094).

J.L.D., J.R. and M.S. conceived and designed the experiments; J.R. performed the experiment; M.N. and J.R. analyzed the data; J.L.D. and M.S. contributed reagents and materials; J.R. and J.L.D. wrote the paper. All authors 
revised and approved the document.

\section{REFERENCES}

[1] Nadal M, Mari M, Schuhmacher M, Domingo JL. Multi-compartmental environmental surveillance of a petrochemical area: Levels of micropollutants. Environ Int 2009; 35(2): 227-35.

[http://dx.doi.org/10.1016/j.envint.2008.06.001] [PMID: 18602160]

[2] Domingo JL, García F, Nadal M, Schuhmacher M. Autopsy tissues as biological monitors of human exposure to environmental pollutants. A case study: Concentrations of metals and PCDD/Fs in subjects living near a hazardous waste incinerator. Environ Res 2017; 154: $269-74$. [http://dx.doi.org/10.1016/j.envres.2017.01.014] [PMID: 28110241]

[3] Valdor PF, Gómez AG, Puente A. Environmental risk analysis of oil handling facilities in port areas. Application to Tarragona harbor (NE Spain). Mar Pollut Bull 2015; 90(1-2): 78-87. [http://dx.doi.org/10.1016/j.marpolbul.2014.11.018] [PMID: 25487087]

[4] Valdor PF, Puente A, Gómez AG, Ondiviela B, Juanes JA. Are environmental risk estimations linked to the actual environmental impact? Application to an oil handling facility (NE Spain). Mar Pollut Bull 2017; 114(2): 941-51. [http://dx.doi.org/10.1016/j.marpolbul.2016.10.078] [PMID: 27865520]

[5] Artiñano B, Gómez-Moreno F, Pujadas M, et al. Measurement of particulate concentrations produced during bulk material handling at the Tarragona harbor. Atmos Environ 2007; 30: 6344-55.

[http://dx.doi.org/10.1016/j.atmosenv.2006.12.020]

[6] Moreno N, Alastuey A, Querol X, et al. Characterisation of dust material emitted during harbour operations (HADA Project). Atmos Environ 41: 6331-43. [http://dx.doi.org/10.1016/j.atmosenv.2007.03.028]

[7] Alastuey A, Moreno N, Querol X, et al. Contribution of harbour activities to levels of particulate matter in a harbour area: Hada ProjectTarragona Spain. Atmos Environ 2007; 41: 6336-78. [http://dx.doi.org/10.1016/j.atmosenv.2007.03.015]

[8] Meteocat Servei Meteorològic de Catalunya Generalitat de Catalunya - Department de Territori i sostenibilitat 2017. Available from: http://www.meteo.cat/observacions/xema/dades

[9] Draxler R, Rolph G. HYSPLIT (Hybrid Single-Particle Lagrangian Integrated Trajectory) Model access via NOAA ARL READY Website. Silver Spring, MD: NOAA Air Resources Laboratory 2017.

[10] Rolph G, Stein A, Stunder B. Real-time environmental applications and display system: READY. Environ Model Softw 2017; 95: 210-28. [http://dx.doi.org/10.1016/j.envsoft.2017.06.025]

[11] U.S. National Committee for Geochemistry. Trace-Element geochemistry of coal resource development related to environmental quality and health. Washington, D.C.: National Academy Press, 1980.

\section{(C) 2018 Rovira et al.}

This is an open access article distributed under the terms of the Creative Commons Attribution 4.0 International Public License (CC-BY 4.0), a copy of which is available at: https://creativecommons.org/licenses/by/4.0/legalcode. This license permits unrestricted use, distribution, and reproduction in any medium, provided the original author and source are credited. 